\title{
Mercury and drought along the lower Carson River, Nevada: IV. Snowy egret post-fledging dispersal, timing of migration and survival, 2002-2004
}

\author{
Charles J. Henny · Elwood F. Hill · Robert A. Grove · Nathan D. Chelgren · Patricia K. Haggerty
}

Submitted: 21 September 2016

Accepted: $\quad$ /Published online:

\begin{abstract}
This telemetry study is an extension of our 1997-2006 research on historical mercury contamination on snowy egrets (Egretta thula) up to $~ 20$ days of age. Findings from initial studies at the mercury-contaminated Carson River colony at Lahontan Reservoir (LR) and a similar-sized reference (REF) colony on the Humboldt River included mercury-related physiological, biochemical, histopathological and reproductive effects up to 20 days of age; with poor water years (2000-04), i.e., reduced prey availability, exacerbating effects. Herein, we compare timing of dispersal and migration at LR vs. REF, but the primary question now addressed is "whether survival of young mercury-exposed snowy egrets from LR would be further compromised beyond 20 days of age?” Based upon telemetry signals until 90-110 days of age (including dead bird counts and survival rate estimates), we conclude that mercury did not further compromise survival. Dead bird counts and survival rate estimates included time in the colony when fed by adults, plus the critical period when young dispersed from the colony to forage independently. The extended drought during this 3-year study was most critical in 2002 when production of $\sim 20$ day old egrets at LR was only 0.24 young/nest. In 2002, survival rates were low at both colonies and we documented the highest counts of dead egrets for both colonies. We suggest the losses in 2002 beyond 20 days of age were more a function of prey availability influenced by drought than exposure to mercury, especially at LR, because higher mercury concentrations, higher survival rates and fewer dead birds were documented at LR in 2003 when water conditions improved. Furthermore, total mercury (THg) in blood in 2003 was more than double 2002 (geometric mean, 3.39 vs $1.47 \mu \mathrm{g} / \mathrm{g}$ wet weight (ww). This higher THg exposure at LR in 2003 was associated with a redistribution of
\end{abstract}


parent and post-dispersal feeding activities upstream (where there was higher mercury from historic mining) related to slightly improved water levels. When comparing the 3-year telemetry findings based upon $\sim 20$ day old young at LR (blood THg, geo. means 1.47, 3.39 and $1.89 \mu \mathrm{g} / \mathrm{g} \mathrm{ww}$ ), we found no evidence that age at dispersal, Julian date at dispersal, timing of migration, or pre-migration survival ( 20 to $\sim 100$ days post-hatch) were adversely affected by elevated mercury.

C.J. Henny (Corresponding Author) - R.A. Grove $\cdot$ N.D. Chelgren · P.K. Haggerty Forest \& Rangeland Ecosystem Science Center, U.S. Geological Survey, 3200 SW Jefferson Way, Corvallis, OR 97331, USA Phone 541 750-1013 E-mail: hennyc@ usgs.gov

E.F. Hill

P.O. Box 1615, Gardnerville, NV 89410, USA

Keywords mercury · snowy egret - mining - drought $\cdot$ telemetry $\cdot$ dispersal $\cdot$ survival $\cdot$ migration $\cdot$ Carson River · Humboldt River · Nevada $\cdot$ USA

\section{Introduction}

An estimated $6.8 \times 10^{6} \mathrm{~kg}$ of elemental mercury were released in mill tailings along the Carson River and its tributaries below Virginia City during the Comstock Lode era of mining from 1859-1890 (Smith 1943; Lawrence 2003). Erosion has since washed much of the contaminated tailings into the floodplains and wetlands of the Lower Carson River System (LCRS) (Fig. 1; Van Denburgh 1973; Hoffman and Thomas 2000). Since the 1915 completion of Lahontan Dam, the resultant 27-km long irrigation reservoir has served as a sink for most of the sediment-bound mercury washed downstream (Hoffman and Taylor 1998). Though the reservoir has spared the agricultural and wetland areas of the Lahontan Valley from substantial mercury contamination for a century, mercury concentrations in some of the stream banks, floodplain sediments and biota of the Carson River Basin including Lahontan Reservoir (LR) are among the highest ever reported in a natural system (Wayne et al. 1996; Wentz et al. 2014). 
The persistence and degree of mercury contamination of the LCRS led to placement of a portion of the basin, including Lahontan Reservoir, on the U.S. Environmental Protection Agency's (EPA) National Priorities "Superfund" list. Studies under this program showed high levels of mercury throughout key ecological components of the LCRS (Ecology and Environment, Inc. 1998). Elevated mercury begins near Brunswick Canyon just east of Carson City and on to the river's terminus in a network of wetlands about 120 to $130 \mathrm{~km}$ downstream in Lahontan Valley, i.e., through the Middle Carson (high mercury) and Carson Desert (lower mercury) Hydrologic Units (HUs); (collectively the LCRS).

Potential toxicity of these mercury concentrations to piscivorous birds was demonstrated in 1997-98 through detection of cellular damage (histopathologic and physiologic) in the nervous, immune, hepatic, and renal systems of young snowy egrets (Egretta thula), black-crowned night-herons (Nycticorax nycticorax) and double-crested cormorants (Phalacrocorax auritus) (Henny et al. 2002). Adult snowy egrets in that study contained high total mercury $(\mathrm{THg})$ concentrations in their livers (geometric; hereafter geo. mean $43.7 \mu \mathrm{g} / \mathrm{g} \mathrm{ww})$ and kidneys $(11.1 \mu \mathrm{g} / \mathrm{g} \mathrm{ww})$, but apparent tolerance of these concentrations was possible due to threshold-dependent demethylation coupled with sequestration of resultant inorganic mercury (IoHg) by selenium (Se) in the liver (Henny et al. 2002). Similar demethylation has been reported in other waterbird species (Eagles-Smith et al. 2009). Demethylation and sequestration processes also appeared to reduce the amount of methylmercury $(\mathrm{MeHg})$ redistributed to eggs. MeHg concentrations in snowy egret eggs at LR did not differ from 1998 to 2005, but in 2006 (a high stream flow year) was higher than all other years (Hill et al. 2008). During the period 1997-2006, $24 \%$ of snowy egret eggs from LR $(n=113)$ and only $2 \%(n=58)$ from a colony of similar species composition and size on the Humboldt River near Elko, NV, (REF) contained $\geq 0.80 \mu \mathrm{g} / \mathrm{g} \mathrm{MeHg}$, the putative reproductive threshold (Hill et al. 2008). Heinz et al. (2009) identified median lethal 
concentration ( $\mathrm{LC}_{50}$ ) values (via egg injection) to $\mathrm{MeHg}$ for 23 species, with 5 species, including the snowy egret considered highly sensitive.

In response to drought in the Great Basin, snowy egret nesting numbers increased at Lahontan Reservoir, which had more stable water levels than marshes/wetlands (Hill et al. 2008). During the extended drought of 2000-04 (Fig. 1), snowy egret nests containing MeHg egg concentrations $\geq 0.80$ $\mu \mathrm{g} / \mathrm{g}$ ww (adjusted for moisture loss) all failed, but in 1997 and 2006 (wet years with general flooding) substantial numbers of young were produced at nests with eggs containing $\geq 0.80 \mu \mathrm{g} / \mathrm{g}$ ww (Hill et al. 2008). This suggests that inter-annual differences in food availability and other habitat factors led to variable toxicity thresholds for survival of young to $\sim 20$ days. During the drought years, assuming all nests with $\geq 0.80 \mu \mathrm{g} / \mathrm{g}$ ww MeHg failed (critical concentration dry years), an estimated $67 \%$ of nests failed with an estimated $21 \%$ failing due to $\mathrm{MeHg}$ concentrations in eggs (Hill et al. 2008). In wetter years of 2005 and 2006, only $18 \%$ and $17 \%$ of nests failed, indicating that $\mathrm{MeHg}$ in eggs $\geq 0.80 \mu \mathrm{g} / \mathrm{g} \mathrm{ww}$ (10\% in 2005 and 90\% in 2006) did not appear as important a cause of nest failure. Similarly, Hallinger and Cristol (2011) noted that high ambient temperatures early in the nesting period were associated with reduced reproductive output of tree swallows (Tachycineta bicolor) in mercury-contaminated birds, but not reference birds. In contrast, they reported little effect of mercury on success of nestlings when temperatures were cooler, and precipitation also had no detectable interaction with mercury. They concluded by raising the possibility that mercury effects may be often masked by weather conditions, with a better understanding of variable environmental conditions needed when assessing effects on freeliving wildlife.

The 10-year annual THg exposure pattern in blood (essentially all $\mathrm{MeHg}$ ) of $~ 20$-day-old egrets at LR was generally higher during years of "normal" water flow and low in drought years, while the colony on the Humboldt showed little annual change (Henny et al. 2007). Variable annual exposure in 
blood of young egrets coupled with a variable reproductive threshold of tolerance to THg (Hill et al. 2008), complicates separation of "mercury effects" from "habitat condition effects". Also, biochemistry and histopathology in the young revealed vacuolar changes in hepatocytes as well as positive correlation of increased liver inflammation with blood and tissue mercury; hepatic oxidative effects were also manifested including evidence of compensatory mechanisms in response to oxidative stress (Hoffman et al. 2009). When plasma variables that differed between the young from LR and REF were compared between wet and drought years, more variables were affected during drought years and were correlated with blood THg, suggesting the drought/mercury combination was potentially more harmful to 20-dayold young than mercury alone.

Our next quest was to determine effects of mercury on young egret dispersal, migration timing and survival until time of migration. This study was conducted during 3 years (2002-04) of drought. Snowy egrets, which feed almost exclusively on aquatic organisms, were studied because their eggs were more sensitive to MeHg than black-crowned night-herons (Henny et al. 2002; Hill et al. 2008). Here we extend the definition of reproductive success from fledgling survival, i.e., 20 days of age, up to migration. Measuring only earlier life stages (e.g., number of fledglings) may produce misleading measures of fitness and population productivity (Streby et al. 2014). To address the question of whether mercury affected the survival beyond the nest, young snowy egrets at two Great Basin populations (LR and REF) were equipped with radio transmitters to evaluate dispersal patterns, timing of migration and survival rates.

Among years (2002-04) and between nesting colonies (LR and REF), we evaluated: (1) age, body weight and blood THg when transmitter radios (radios) were attached, (2) age at dispersal from natal areas, (3) Julian date at dispersal, (4) weekly minimum movement and distance from the natal area, (5) geographical dispersal patterns, (6) timing of migration, and (7) number of documented deaths and 
model-derived survival rates between $\sim 20$ days and migration. Over the 10-year study, the REF was useful for comparison to the LR colony for basic toxicology and reproduction through $\sim 20$ days of age. The comparative approach, when used in field studies like this, assumes "all factors" were equivalent except mercury exposure. This assumption was tested through evaluation of post-dispersal success for closed small stream association versus open wetland.

\section{Methods}

Study sites

Field studies were of similar mixed-species nesting colonies on Gull Island in the northeastern portion of Lahontan Reservoir in the Carson River drainage, and another near Ryndon on the Humboldt River about $16 \mathrm{~km}$ east of Elko, NV (Fig. 1). Though separated by $\sim 350 \mathrm{~km}$, these populations were exposed to similar annual water conditions in the Great Basin, but Gull Island is isolated off-shore in a fluctuating irrigation reservoir; whereas the Ryndon colony was in a narrow riverine setting. Lahontan Reservoir--Gull Island: Snowy egrets nested primarily in saltcedar (tamarisk; Tamarix spp.) along the eastern perimeter of Gull Island. During good water years, the saltcedar was nearly impenetrable and provided protection of eggs and nestlings from avian predators. Large numbers of ring-billed and California gulls (Larus delawarensis and L. californicus) nested on open ground adjacent to the egret colony. During poor water years, saltcedar foliage was sparse and many egret nests were exposed to mid-day sun, high winds and avian predation. During years of early water draw-down, vegetated shallows around the island that would normally harbor prey for wading birds were generally absent by the time young snowy egrets departed their nests in search of food. Thus, during poor water years the young egrets could not forage in the shallows around the colony and were entirely dependent upon adults delivering food gathered away from the island, i.e., more vulnerable to food shortages. 
Humboldt River-Ryndon: The Ryndon colony nested in a dense stand of willows (Salix sp.) along the river, within the flood plain, mostly over water and included snowy, great (Ardea alba), and cattle egrets (Bubulcus ibis), and black-crowned night-herons. Though the species composition of the two colonies is predominately snowy egret, the surrounding ecotypes are markedly different. Gull Island is in a large reservoir just upstream of expansive wetlands; whereas the Ryndon colony is near the river's headwaters and surrounded by semi-desert sagebrush (Artemisia spp.) steppe.

\section{Bird Sampling}

Blood samples were collected for biochemistry and mercury analysis from snowy egrets fitted with radios. The preferred criteria for egret selection was one per nest and having either bill length or body mass exceeding $4.0 \mathrm{~cm}$ or $250 \mathrm{~g}$. Bill length was used to estimate age in days (Custer and Peterson 1991). Blood samples ( $2 \mathrm{ml}$ ) were drawn by jugular venipuncture (23-ga needle) into a lithiumheparinized syringe. Details of blood sampling and analytical chemistry are provided in Hill et al. (2008). All animal procedures were approved by the Institutional Animal Care and Use Committee of the U. S. Geological Survey (USGS) Forest and Rangeland Ecosystem Science Center.

\section{Radio Telemetry}

Radios were attached to snowy egrets at about 20 days of age. The goal was to radio $20-25$ young per year at both colonies. The 8.9-g radio units (Advanced Telemetry Systems, Inc., Isanti, MN) were attached to a standard aluminum USGS \#6 leg band, which was placed on the tibiotarsis above the tarsometatarsal joint (Erwin et al. 1996a). The radio-band configuration was based on the 3\% of body weight guideline of the U.S. Bird Banding Laboratory, Laurel, MD. Expected radio life was 3 to 4 months, and included a mortality switch. Ground surveys to monitor dispersal from the natal areas were conducted at least twice weekly from the time radios were attached through dispersal of the young. The dispersal date was calculated as the midway date between the last day observed at the colony and the 
first day absent from the colony. Age at dispersal was based upon the estimated age in days when each radio was attached, plus the number of days a bird remained at the colony.

Aerial surveys were flown using a Cessna 172 aircraft equipped with two side-looking Yagi antennas from $~ 300$ meters above the ground surface as described by Gilmer et al. (1981), with locations determined using the aircraft's global positioning system. Most locations were in narrow riparian zones, on small reservoirs, or in larger wetlands in this generally arid region. Most birds were located during each survey prior to migration. Aerial surveys were conducted weekly following dispersal until nearly all young departed the Carson and Humboldt River Systems. Each aerial survey included the Lahontan Valley, the Carson River, and major wetlands and lakes in western Nevada and along the full length of the Humboldt River and its upper tributaries. Occasional ground and aerial surveys were also conducted at prominent wetlands across southwestern Idaho, northern Nevada and eastern slopes of the Sierra Nevada from Honey Lake to Mono Lake, California.

\section{Dataset and Dispersal Plotting Procedures}

The proportional number of telemetered young that died prior to and after dispersal were compared between colonies and among years. Coordinate information from the field surveys and flights was entered into a GIS system (ArcGIS10). Each observation was validated by aerial photography as being within a reasonable envelope around egret habitat, e.g., streams, ponds/lakes. Questionable locations were reviewed with field observers. Validated locations were translated into segmented travel paths for each individual using the "Polar Plots and Circular Statistics Extension for ArcGIS" (Jenness 2012). Minimum distance traveled between weekly observations and Euclidean distance from the natal colony for each location was calculated and summarized by age (days) and Julian date for each individual.

Locations were summarized by Hydrologic Units (HUs) as represented in the high resolution version of the Watershed Boundary Dataset (WBD) (USGS 2008). Some adjacent units of the 
Humboldt River in the WBD were combined to better represent egret usage between the river and its tributaries and the extent of the Carson River and Humboldt River was limited to $~ 95 \mathrm{~km}$ from the natal colony, the furthest extent of egret locations. In order to make a general assessment of habitat availability and estimate change between years for the period of egret dispersal, land use classification was determined for the LR and the REF HUs from the National Land Cover Dataset of 2001. As a measure of annual condition, Normalized Difference Vegetation Index (NDVI) was generated for late August/early September of each year, 2002 through 2004, using a clear sky Landsat 5 TM imagery selected from the USGS Landsat Archive. Land cover and NDVI analysis was restricted to low elevation/low slope areas within the HUs, representative of the wetland and riparian areas used by the egrets. NDVI was calculated using the ENVI 5 software.

\section{Timing of Migration Procedures}

For each weekly flight, the percentage of dispersed birds detected (alive or dead) from each colony (minus those never detected after dispersing and those that died in previous weeks) was evaluated. When a bird was missed during a survey but detected alive later (an infrequent event), it was considered alive during the period missed. The limited wetlands were easily surveyed by air in one day. To further evaluate "timing of migration" (as opposed to perhaps radio failure over time), annual timing patterns from each colony were compared with the bird's age and the Julian date at dispersal.

\section{Statistical Procedures}

THg residue concentrations were log-transformed for summarization as geometric means prior to statistical analyses. Due to unequal sample sizes, the General Linear Models Procedure (SAS Institute 1999) was used for analysis of variance (ANOVA). Tukey's Studentized Range Test $(\mathrm{P}=0.05)$ was used to separate means. Chi-square $\left(\mathrm{X}^{2}\right)$ tests with $1 \mathrm{df}$ were used to test binomial proportions of those dying (LR vs. REF) at colony before dispersal, after dispersal, and combined. In addition, the known 
fate model of program MARK with the logit link function (White and Burnham 1999) was used to estimate daily survival rates (DSRs) for egrets from the time of radio attachment. Separate survival rates were estimated for each year and location in addition to pre- and post-dispersal periods. Birds were censored from the survival analysis on the last day the radio was located. Censoring usually occurred in mid- to late-September and occasionally in early October when egrets migrated from the study areas.

A full model was fitted where survival rates varied fully by site, by year and by pre- and postdispersal periods, with all interactions (model Site x Year x Dispersal), for a total of 12 parameters. The full model fit the data adequately according to the deviance/df $=0.3429$. Values $>1.0$ would be indicative of a poor fit to the model. A parsimonious model was sought to address the most important question, i.e., was the survival rate different at the LR compared to the REF? Against the full model, it was asked whether pre and post-dispersal periods could be combined (model Site x Year), whether years could be combined (model Site x Dispersal), and whether years and dispersal periods could be combined (model Site). Akaike's Information Criterion favored model Site x Year as the most parsimonious in terms of model fit and number of parameters. We then used likelihood ratio tests between the selected parsimonious model and reduced models where site differences were removed.

\begin{tabular}{|c|c|c|c|c|}
\hline Model & Delta $\mathrm{AIC}_{\mathrm{c}}$ & $\begin{array}{l}\text { Number of } \\
\text { Parameters }\end{array}$ & Model Weight & Deviance \\
\hline Site $\mathrm{x}$ Year & 0 & 6 & 0.79 & 215.4 \\
\hline Site x Year x Dispersal & 2.8 & 12 & 0.20 & 206.1 \\
\hline Site x Dispersal & 9.9 & 4 & 0.06 & 229.3 \\
\hline Site & 16.0 & 2 & 0.00 & 239.4 \\
\hline
\end{tabular}


Then, in a separate analysis, using the subset of egrets with individual blood THg concentrations measured, we fit two models to determine the extent to which individual blood THg explained year and site differences in survival. Because of the reduced sample size (69 individuals at LR and 17 individuals at REF), full Site x Year could not be considered simultaneously with the THg effects. We fit a year by THg interaction model Year $\mathrm{x}$ THg and an additive model Year $+\mathrm{THg}$, examined the magnitude of the THg coefficients and determined significance by likelihood ratio tests against reduced models where the THg effect was removed.

\begin{tabular}{|c|c|c|c|c|}
\hline Model & Delta $\mathrm{AIC}_{\mathrm{c}}$ & $\begin{array}{l}\text { Number of } \\
\text { Parameters }\end{array}$ & Model Weight & Deviance \\
\hline Year + THg & 0 & 4 & 0.74 & 278.5 \\
\hline Year x THg & 2.1 & 6 & 0.26 & 276.6 \\
\hline
\end{tabular}

\section{Results}

Mercury Exposure, Age and Date at Dispersal

Snowy egrets were about 18 to $20 \mathrm{~d}$ old when radios were attached (Table 1). Mean age was not significantly different between the two study areas in 2002 and 2004, but young in 2003 were about 10\% older and heavier at the REF, while blood THg was generally 2 - to 5-fold higher at LR (Table 1). In 2003, THg at LR (3.39 $\mu \mathrm{g} / \mathrm{g} \mathrm{ww})$ was about 2.3 and 1.8-fold higher than in 2002 and 2004, but only significantly different from 2002 .

After radio attachment, young generally remained at the natal colony for about a month prior to dispersal (Table 2). Age at dispersal at LR was significantly younger in 2003 than in 2004; inadequate data were available for 2002 as only three dispersed. Dispersal at the REF occurred at a significantly younger age in both 2002 and 2003, than in 2004. However, age at dispersal between colonies did not differ significantly in either 2003 or 2004. 
Mean age at dispersal does not relate directly to the mean Julian date of dispersal because egg laying/hatch date vary from year to year, thus age at dispersal was converted to Julian date (Table 2). The mean "Julian hatch date" for radioed egrets that dispersed was also calculated (Julian dispersal date, minus age at dispersal) for LR $(2002,168.0 ; 2003,174.5 ; 2004,154.2)$ and for REF $(2002,173.2 ; 2003$, 173.7; 2004 155.3). Mean Julian date for dispersal at both LR and REF in 2004 was the earliest and identical (209.7 and 209.7), while the mean age at dispersal was within a day (55.5 and 54.4 days). The Julian dates for dispersal in 2004 were 10 to 15 days earlier than at either site in 2002 or 2003. Excluding LR 2002 (small sample), no significant difference in age at dispersal or Julian date of dispersal was detected between colonies during the same year.

\section{Timing of Documented Deaths}

One nestling had its radio snagged on a branch; it died at the colony and was eliminated from the dataset. During this 3-year study, 41 of $150(27.3 \%)$ radioed snowy egrets were documented as dead prior to migration (Table 3). Deaths were categorized as either "in colony" or between dispersal and migration. The year-to-year pattern of deaths "in colony" at the REF was consistent and low with a 3year mean of 3.8\%. At LR, "in colony" deaths were especially high in 2002 (7/10) compared to 2003 (1/23) and 2004 (6/38) with only results from 2003 within the REF range. The specific age at death while "in colony" did not appear to differ between colonies (Suppl. Table 1). Only three egrets died within 10-days after radio attachment (28, 28 and 29 days old). A lower percentage (9.3\%) of LR birds that dispersed were documented dead prior to migration during the 3-year study, which contrasted with a higher percentage $(25.3 \%)$ at the $\operatorname{REF}(\mathrm{P}=0.021)$.

\section{Water Conditions and Geographical Pattern of Dispersal}

The Great Basin is noted for wide fluctuation in precipitation. Coincidentally, this study was conducted during an extended drought. Low annual discharge years for the Carson River from 2000 to 2004 (Fig. 
1) resulted in a critical reduction of wetlands throughout the LCRS. These differences were indicated by wetland patterns for the Stillwater National Wildlife Refuge (NWR), a representative fraction of the Carson Desert HU (Fig. 2). Total annual discharge (cfs) in the Humboldt River generally paralleled the long-term pattern observed on the Carson River. Geographical dispersal patterns were plotted based upon Hydrologic Units which included annual Normalized Difference Vegetation Index (NDVI) values for late August-early September. NDVI values $>0.2$ represented full cover vegetated areas as opposed to minimal vegetation, soil or water (Nagler et al. 2009). Our study areas met this criterion for similar desert habitats with conspicuous riparian systems modified by irrigation for intensive agriculture. The LCRS has expansive wetlands at its terminus in the Lahontan Valley, whereas the REF area and feeder streams to the Humboldt River are closely surrounded by sagebrush steppe. The area of these moderate to high NDVI values $>0.2$ were summed by HU (Suppl. Table 2). The most substantial NDVI change was a 32\% reduction in Middle Carson HU (high mercury zone) from 2003 to 2004.

Lahontan Reservoir Population: Blood THg concentrations in young egrets varied widely from year to year at LR and were highest in 2003 (Table 1). Some drought relief occurred in 2003 (Fig. 1) when Lahontan Reservoir was filled to $\sim 78 \%$ of its capacity through June, with water remaining in the shallows at the upper end of the reservoir into September. These nearby shallows in 2003, about 10-15 $\mathrm{km}$ upstream from the colony site, were used extensively by radioed young egrets prior to their moving 45-55 km further upstream into the Dayton Valley, where many remained until fall migration (Fig. 2, Suppl. Table 3). Many adults from the colony (though not radioed), but as reflected in blood of their 20-day-old flightless young, presumably also foraged in those shallows early in the 2003 nesting cycle. The shallows were much closer to the colony than downstream wetlands. Observations of dispersed egrets in 2003 included 70.3\% in the Middle Carson HU and 23.4\% downstream in the Carson Desert HU. Thus, $93.7 \%$ of observations in 2003 were from two HUs contaminated by Comstock mercury. 
Though the Lahontan Reservoir level in June of 2004 was similar to 2003, irrigation water was removed earlier in 2004 which exposed and dried out the shallow foraging areas at the upper end of Lahontan Reservoir. These water and habitat changes forced egrets to feed elsewhere. Dispersal observations in the nearby Middle Carson HU in 2003 (70.3\%) contrasted dramatically with 2004 (16.4\%). Most egret observations were downstream from the natal area in the Carson Desert HU in 2004 (69.6\%) (Fig. 2, Suppl. Table 3). Egrets dispersing outside the influence of the Comstock Lode era mining activities included $10.3 \%$ of observations in 2003-04, with about half (5.2\%) from the Upper Carson HU, which is upstream of historic mining activities.

Whereas a few individuals made some long weekly movements (e.g., 75 to $95 \mathrm{~km}$ ) in both 2003 and 2004, most moved considerably less beginning at age 7 to 9 weeks. Dispersal distance was further during this 3-week period in 2004 when many of the young moved downstream (Suppl. Fig. 1, Suppl. Table 3), as opposed to upstream in 2003 when nearby water conditions and riverine habitat were more acceptable. Weeks 10 to 14 showed considerably less weekly movement, and distance from natal area stabilized. The mean distance dispersed from the natal colony in both 2003 and 2004 was about 40 to 50 $\mathrm{km}$.

Humboldt River Reference Population: Two HUs (Mary's River and Reed Creek-Humboldt) to the east and north of the REF colony were most used by dispersing young in all years (Fig. 3, Suppl. Fig. 2, Suppl. Table 4). Some egrets dispersed north along the Mary's River to nearly its origin. Two other HUs, Lemoille-Secret Creek and South Fork Humboldt River and Reservoir, were important for dispersing snowy egrets, especially in 2002 and 2003.

A few individuals at the REF, as at LR, made weekly movements up to $95 \mathrm{~km}$ each year (Suppl. Fig. 2). Most weekly dispersal movement occurred during weeks 8 to10 and then tapered off as the distance from the natal colony stabilized. Mean distance moved from the natal area was generally $~ 30-$ 
$40 \mathrm{~km}$ in 2002 and 2003, but up to $50 \mathrm{~km}$ in 2004 when fewer egrets stayed near the natal area at Secret Creek.

A slight increase in annual discharge from 2002 occurred on the Humboldt River during this 3year study, whereas the Carson River showed some improvement in 2003 which resulted in changes in snowy egret dispersal patterns (Suppl. Table 3) and THg exposure (Table 1). Though some year-to-year fluctuations occurred in dispersal patterns from the REF, THg annual exposure based upon blood from young was consistent (0.67- $0.71 \mu \mathrm{g} / \mathrm{g} \mathrm{ww}$; Table 1$)$ and similar to THg concentrations reported from the REF during the long-term study (Henny et al. 2007). Thus, we conclude that background THg in blood of young snowy egrets at REF is $<1.0 \mu \mathrm{g} / \mathrm{g} w \mathrm{w}$, and clearly less than measured repeatedly at LR.

\section{Timing of Annual Fall Migration}

Timing of fall migration from both colonies was estimated from the presence of radio signals from live birds recorded during weekly flights and plotted against Julian date (Fig. 4). Fall migration from both colonies in 2004 was earlier than from LR in 2003 and REF in 2002 and 2003. By the end of September 2004, all young migrated from the REF and about $75 \%$ from LR.

Timing of the nesting season may play a role in the timing of migration. By evaluating the mean Julian date of dispersal minus the mean age at dispersal (Table 2), the Julian hatch date was estimated specifically for radioed egrets monitored from each study area and year. Mean Julian hatch dates for 2002, 2003 and 2004 were: REF 172.8, 174.6, and 155.0, and LR 168.0, 174.4, and 155.8. The nesting season in 2004 was 19-20 days earlier at both study areas than in 2003. Even with 2004 dispersal age 56 days older at each colony, the young still dispersed about 2 weeks earlier in 2004 than in 2003 at both sites when fall migration at both sites took place earlier (Fig. 4). Young snowy egrets migrated from about mid-September through early October.

\section{Survival Rates}


In addition to the recorded known deaths summarized earlier, model-derived survival rate estimates were developed and likewise include about one month in the natal colony plus up to $2+$ months postdispersal prior to migration. Parameter estimates for model Site $\mathrm{x}$ Year revealed that most of the variation in daily survival rate was attributable to the 2002 season (Fig. 5, Suppl. Table 5). Using model Site $\mathrm{x}$ Year, best supported by $\mathrm{AIC}_{\mathrm{c}}$, we proceeded to test whether there was a site effect in each year separately using likelihood ratio tests against reduced models where the year-specific site effect was removed. Survival was lower at LR, than at the REF in 2002, when only 3 of 10 egrets dispersed from Gull Island $\left(\mathrm{X}^{2}=3.403,1 \mathrm{df}, \mathrm{P}=0.0651\right)$. In contrast, survival rates were reversed for the two areas in 2003 and 2004, though differences were not significant $\left(X^{2}=1.1602,1 \mathrm{df}, \mathrm{P}=0.2056\right)$ and $\left(\mathrm{X}^{2}=0.043\right.$, $1 \mathrm{df}, \mathrm{P}=0.8364)$. Though not the best supported model, the full model Site $\mathrm{x}$ Year $\mathrm{x}$ Dispersal was competitive (delta $\mathrm{AIC}_{\mathrm{c}}=2.8$, model weight 0.20 ); using the full model, the only significance difference between sites was in 2002 during the pre-dispersal period $\left(\mathrm{X}^{2}=6.516,1 \mathrm{df}, \mathrm{P}=0.0107\right)$. Likelihood ratio tests associated with the full model are presented in Suppl. Table 6. We extrapolated estimates of DSR, i.e., $\mathrm{DSR}^{30}$ from our best approximating model, with variances estimated by the Delta method (Seber 1972, Fig. 5 for pre- and post-dispersal periods, Suppl. Table 7).

Blood THg concentrations were measured for 69 and 17 individuals at LR and REF (Fig. 5). We then estimated the effect of a $1.0 \mathrm{THg} \mu \mathrm{g} / \mathrm{g}$ increase in blood on the odds of survival. If we consider a common survival rate for individuals of the same THg level at the two sites, model Year $+\mathrm{THg}$, best supported by AIC, the odds of surviving decrease by a factor of $0.917(0.306-2.753)$ for each $1.0 \mu \mathrm{g} / \mathrm{g}$ increase in blood $\mathrm{THg}$, though this effect was not significant $\left(\mathrm{X}^{2}=0.075,1 \mathrm{df}, \mathrm{P}=0.785\right)$. Based on model Year $\mathrm{x}$ THg, having some support (delta $\mathrm{AIC}_{\mathrm{c}}=2.1$ ), year-specific estimates of the multiplicative change in odds of surviving for a unit increase in $\mu \mathrm{g} / \mathrm{g}$ ranged from 0.544 to 1.381 times, none of the year-specific effects were significant. 


\begin{tabular}{|ccc|}
\hline Year & Odds Ratio (Confidence Limits) & $\mathrm{P}$ \\
\hline 2002 & $0.544(0.222-1.333)$ & 0.213 \\
2003 & $1.090(0.326-3.641)$ & 0.887 \\
2004 & $1.381(0.514-3.707)$ & 0.522 \\
\hline Odds ratio = Probability (surviving)/(1-Probability (surviving)) \\
\hline
\end{tabular}

\section{Discussion and Conclusions}

This 2002-2004 study was during a 5-year drought. Water conditions temporarily improved in the LCRS in 2003 and resulted in a change in dispersal patterns of young and foraging patterns of adults. THg in blood of young snowy egrets was higher in 2003, when more contaminated nearby shallows upstream became foraging destinations in contrast to the downstream less mercury-contaminated Carson Desert HU. Seeing young snowy egrets remain in the more contaminated Middle Carson HU, especially the Dayton Valley in 2003, raised concern about continued accumulation of mercury prior to migration. Additional mercury accumulation was expected after completion of feather growth, which occurs within a few weeks after attaining flight (Palmer 1962; Spalding et al. 2000). To check for additional THg accumulation, we collected one unmarked young downstream of Lahontan Reservoir at Stillwater NWR on 9 September 2004. Its blood THg was $4.61 \mu \mathrm{g} / \mathrm{g} \mathrm{ww}$, which was higher than all $\sim 20$-day old snowy egrets $(\mathrm{n}=43)$ sampled at LR between 19 June and 9 July 2004 (extremes 1.04-3.04 $\mu \mathrm{g} / \mathrm{g} \mathrm{ww})$. Thus, assuming the young egret collected at Stillwater NWR was from LR (only active colony in LCRS), it continued to accumulate mercury before migration and suggests a higher mercury load at migration than indicated by our nestling bleedings. Three adults collected at the same location and date had higher THg in blood (5.07, 5.35, and $6.87 \mu \mathrm{g} / \mathrm{g} \mathrm{ww})$, but similar THg values were found in four adults collected at LR in June-July 1998 (geo. mean $5.86 \mu \mathrm{g} / \mathrm{g} \mathrm{ww}$, extremes 2.79 and 10.36) (Henny et al. 2002). Threshold-dependent demethylation of $\mathrm{MeHg}$ and sequestration of resultant $\mathrm{IoHg}$ by Se in adult livers may be the reason for stable mercury concentrations in the blood of adults. Thus, limited evidence 
indicates that young egrets continued to accumulate mercury prior to migration in 2004, and perhaps much more in 2003 when most dispersed upstream into the more mercury-contaminated Middle Carson HU.

Initial project findings showed that organ $\mathrm{THg}$ concentrations in adult snowy egrets were much higher than in young (Henny et al. 2002). However, these adults showed no overt toxicity, but pathological and physiological evaluations of young indicated potentially toxic changes in immune (spleen, thymus, bursa), detoxicating (liver, kidneys) and nervous systems. How do the mercury accumulation patterns at both sites during this 3-year study compare to the 1998 study when toxic effects were initially noted? Blood, eggs and a few carcasses were collected each year at both sites and compared with 1998 data (Henny et al. 2002; Henny et al. 2007; Hill et al. 2008; Hoffman et al. 2009). LR young in 1998 had geometric mean THg concentrations similar to those collected in 2002-04: liver (2.74 vs. $2.40-3.06 \mu \mathrm{g} / \mathrm{g} w w)$, kidney (2.19 vs. $1.78-2.46 \mu \mathrm{g} / \mathrm{g}$ ww), brain (0.70 vs. $0.70-0.93 \mu \mathrm{g} / \mathrm{g} \mathrm{ww}$ ), and blood (2.67 vs. 1.47-3.39 $\mu \mathrm{g} / \mathrm{g}$ ww). Similar studies of young snowy egrets from the REF site in 2002-04 were consistently lower than those from LR, though snowy egrets from the REF were not mercury-free, e.g., liver 0.76-0.86 $\mu \mathrm{g} / \mathrm{g} w \mathrm{w}$, kidney $0.55-0.64 \mu \mathrm{g} / \mathrm{g} w \mathrm{w}$, brain 0.19-0.23 $\mu \mathrm{g} / \mathrm{g} w \mathrm{w}$, and feathers 6.66-8.50 $\mu \mathrm{g} / \mathrm{g}$ ww. Radioed egrets at LR changed foraging areas to upstream on the Carson River in 2003 in response to changing water conditions, which resulted in significantly higher THg concentrations in blood from young in 2003 than in 2002, but also higher concentrations in liver, kidney and feathers (Hoffman et al. 2009). THg blood concentrations in 2004 were similar to 2002. Thus, the physiological and biochemical effects observed and correlated with mercury concentrations in $\sim 20$-dayold young raised questions about later survival when confronted with new landscapes and learning to forage. 
Changes in the dispersal pattern and distance moved from LR were a function of water conditions. Longer dispersal movements were observed in weeks 7-9 in 2004 because the nearby upstream foraging area in 2003 was no longer suitable. However, the mean distance dispersed from the LR colony was similar in 2003 and 2004 (40-45 km). In contrast, THg concentrations at the REF showed little annual variability with most birds dispersing to Mary's River and Reed Creek-Humboldt. Mean distance dispersed from the natal area was $35-40 \mathrm{~km}$ in 2002 and 2003, but a bit further to $\sim 45 \mathrm{~km}$ in 2004 when fewer egrets remained closer to the natal area at Secret Creek. The few long distance explorers observed from both Nevada sites may be critical to long-term population health with fluctuating water conditions in the Great Basin. As mentioned, dispersal patterns and mean distances were similar for both Nevada colonies (35-45 km). By comparison in a Virginia study, snowy egrets dispersed mean distances of $50 \mathrm{~km}$ (1992) and $125 \mathrm{~km}$ (1993) (Erwin et al. 1996a). However, the Virginia study area was continuous coastal habitat which differed considerably from the Great Basin of Nevada where suitable habitat was patchy and extremely limited (wetlands, small rivers and streams). Dispersal patterns in Nevada were a function of limited and annual water availability.

Mean age at dispersal varied from 47 to 55 days in our 3-year Nevada study. In Virginia, 39 of 40 snowy egrets dispersed from the natal colony (radioed only largest chick, which had higher survival rates; Erwin et al. [1996a, 1996b]). The mean age at dispersal during the 2-year Virginia study was comparable (53.0 and 56.3 days) to Nevada. Age at dispersal was not significantly different between LR and REF during the same year, but varied together from year to year. The nesting season was 19-20 days earlier at both colonies in 2004 compared to 2003, but with dispersal age 5-6 days older at both colonies in 2004. Thus, snowy egret young still dispersed about 2 weeks earlier at both colonies in 2004 than 2003. Migration also occurred about 2 weeks earlier from both LR and REF in 2004 than 2003. A comparison of LR and REF strongly suggests that reproductive phenology plus dispersal and 
migration timing were not altered by elevated mercury at LR. This lack of overt toxicity suggests that any change in post-dispersal survival is more likely a function of environmental challenge rather than exposure to mercury.

Post-dispersal is a vulnerable period. Newton (1986) reported heavy mortality of newly independent juvenile Eurasian sparrowhawks (Accipiter nisus) in August and September, largely due to starvation in spite of plentiful prey. Although young egrets may require less refined hunting skills, their inexperience makes them vulnerable to land and avian predators in addition to starvation. This may be especially problematic for young egrets foraging alone along small streams (REF) rather than in large established wetlands (LR). Thus, a considerable number of deaths was expected during the first $\sim 100$ days after radio-attachment when young were becoming independent of adults. During the 3-year study (years combined), timing of documented deaths differed from LR (high "in colony" [19.7\%], low postdispersal [9.3\%]) and REF (low “in colony”[3.8\%], high post-dispersal [25.3\%]). The above notion of differential post-dispersal vulnerability is supported by the significantly higher $(\mathrm{P}=0.021)$ incidence of post-dispersal deaths (25.3\%) from the REF compared to the LR (9.3\%), which cannot logically be attributed to mercury. Thus, the concept that "all factors" except mercury were equivalent at both sites in this study was not bourne out, especially during the post-dispersal period. As described previously, where factors within the colonies were generally compatible and with parental protection and feeding, post-dispersal challenges were different making the REF egrets potentially more subject to inexperience and possibly predation.

What about mercury and its possible negative effect on "in colony" deaths which were significantly higher $(\mathrm{P}=0.002)$ at $\mathrm{LR}($ mean $19.7 \%$, extremes $4.3-70 \%)$ compared to a consistent pattern at REF (mean 3.8\%, extremes 2.9-5.0\%)? The "in colony" deaths at LR in 2003 (year with highest THg in blood [3.39 $\mu \mathrm{g} / \mathrm{g} \mathrm{ww}$, but adults foraged nearby) may be particularly instructive since only $4.3 \%$ died 
(well within range of REF 2.9-5.0\%). In 2002 and 2004 at LR, when 70\% and 15.8\% died at colony, mercury in blood of flightless young was lower (1.47 and $1.89 \mu \mathrm{g} / \mathrm{g} \mathrm{ww})$ indicating that many adults foraged downstream in Carson Desert HU (lower mercury) and farther away when the local foraging area dried up.

Thus, the highest mercury concentrations were not associated with high "in colony" documented deaths at LR. Instead, the overriding factor appeared to be food availability. The much higher percentage of post-dispersal deaths on the Humboldt points to the challenge of conducting contaminantrelated studies under field conditions. All factors, except mercury, are seldom equal under field conditions. Detailed foraging ecology studies at both locations would be informative. Although the timing of deaths differed between colonies, no significant difference was found in the 3-year totals ("in colony" + post-dispersal) documented as dead prior to migration (LR 19 of 71, 26.8\% vs. REF 22 of 79, $27.8 \% ; \mathrm{P}=0.639)$.

Model-related survival rates were also estimated with a null hypothesis of equal survival rates during the $\sim 100$ days after radio attachment for both LR and REF. The model Site $\mathrm{x}$ Year showed that most of the variation in daily survival rates was attributable to the 2002 season (Suppl. Table 5, 6). Survival rate estimates for snowy egrets in 2002, an extreme drought year, were considerably lower for both colonies than in either 2003 or 2004 and in agreement with the dead egrets documented. Furthermore, the 2002 LR survival rate estimate appeared lower than for the 2002 REF population $(\mathrm{P}=$ 0.0651). Drought conditions undoubtedly reduced food availability for young, which in turn lowered survival rates for both populations. The percentage of nests successful at LR was extremely low in 2002, with few young produced to 20 days of age. It was noted that $60 \%$ of nests at LR in 2002 contained $\mathrm{THg}$ concentrations in eggs $\geq 0.80 \mu \mathrm{g} / \mathrm{g}$, i.e., the putative threshold where reproductive problems (to $\sim 20$ days of age) occur during drought years--those nests produced no young (Hill et al. 
2008). Then, a continuation of reproductive problems occurred beyond $\sim 20$ days of age at LR in 2002 , when 7 of 10 radioed snowy egrets died "in colony" before dispersing. Drought and its effects on food distribution and availability plus mercury appear linked to young produced to $\sim 20$ days of age, i.e., the variable reproductive threshold of tolerance (Hill et al. 2008). Although mentioned earlier, it is doubtful that survival beyond 20 days was influenced by mercury at LR in 2002. This conclusion is based upon mercury concentrations in both colonies at $\sim 20$ days of age in 2002 and 2003. THg and MeHg in blood, liver and kidneys were consistently lower at LR in 2002 (the lower survival year) than in 2003 (the higher survival year), but food (although assumed more MeHg contaminated in 2003) was readily available nearby in the upper reaches of Lahontan Reservoir. Meanwhile, $\mathrm{THg}$ and $\mathrm{MeHg}$ concentrations were unchanged at the REF in 2002 (the lower survival year) and 2003 (the higher survival year). We believe drought alone was the common factor for both colonies in 2002 and was responsible for the lower survival rates beyond $\sim 20$ days that year. In fact, point estimates of survival rates were higher at LR than the REF in both 2003 and 2004, though were not significantly different. Though data were limited (fewer egrets were analyzed for mercury at REF), an odds ratio approach to survival in relation to individual blood THg concentrations also failed to show a significant effect of mercury on survival. D.A. Cristol (pers. comm.) reviewed ten survival/longevity papers on birds/mercury and concluded that mercury, at environmentally relevant concentrations, does not appear to directly decrease longevity. Mercury-related problems, when they occurred in Nevada, appeared early in the reproductive cycle, i.e., while at the nesting colony.

Acknowledgments This study received partial funding from the U.S. Environmental Protection Agency (National Center for Environmental Assessment, Washington, DC and Region 9, Superfund Division, San Francisco, CA). Assistance with field sampling and radio telemetry was provided by Keith Penner, Paul Schmidt, Rob Holly and Jim Sizemore of the Nevada Division of Parks at Lahontan 
Reservoir and Peter Bradley, Julian Pelligrini, Caleb MacAdoo, and Andi Kemmerer of the Nevada Department of Wildlife, Elko. Larry Neel and Jennifer Jeffers, Nevada Department of Wildlife, Fallon and Bill Henry, U.S. Fish \& Wildlife Service (USFWS), Fallon, provided information on birds nesting at other locations in the LCRS. Angela Paul and Karen Thomas, USGS, Carson City, kindly provided water data for the Carson River system. Marcus Rudnick provided access to private land on the Humboldt River. Walt Wardwell, Fallon Airmotive, was pilot for all telemetry surveys and provided expertise on location of streams, lakes and wetlands. Early drafts were improved by comments from Gary Heinz and Dan Cristol. Any use of trade, firm, or product names is for descriptive purposes only and does not imply endorsement by the U.S. Government.

\section{References}

Custer TW, Peterson DW, Jr (1991) Growth rates of great egret, snowy egret and black-crowned night-heron chicks. Colonial Waterbirds 14:46-50

Eagles-Smith CA, Ackerman JT, Yee J, Adelsbach TL (2009) Mercury demethylation in waterbird livers: dose-response thresholds and differences among species. Environ Toxicol Chem 28:568-577

Ecology and Environment, Inc. (1998) Draft Ecological Risk Assessment, 001-98, Carson River Mercury Site, San Francisco

Erwin RM, Haig JG, Stotts DB, Hatfield JS (1996a) Dispersal and habitat use by post-fledging juvenile snowy egrets and black-crowned night-herons. Wilson Bull 108:342-356

Erwin RM, Haig JG, Stotts DB, Hatfield JS (1996b) Reproductive success, growth and survival of black-crowned night-heron (Nycticorax nycticorax) and snowy egret (Egretta thula) chicks in coastal Virginia. Auk 113:119-130

Gilmer DS, Cowardin LM, Duval RL, Mechlin LM, Shaiffer CW, Kuechle VB (1981) Procedures for 
the use of aircraft in wildlife biotelemetry studies. U S Fish and Wildlife Service, Resource Publ 140

Hallinger KK, Cristol DA (2011) The role of weather in mediating the effect of mercury exposure on reproductive success of tree swallows. Ecotoxicology 20:1368-1377

Heinz GH, Hoffman DJ, Klimstra JD, Stebbins KR, Kondrad SL, Erwin CA ( 2009) Species differences in the sensitivity of avian embryos to methylmercury. Arch Environ Contam Toxicol 56:129138

Henny CJ, Hill EF, Hoffman DJ, Spalding MG, Grove RA (2002) Nineteenth century mercury: Hazard to wading birds and cormorants of the Carson River, Nevada. Ecotoxicology 11:213231

Henny CJ, Hill EF, Grove RA, Kaiser JL (2007) Mercury and drought along the lower Carson River, Nevada: I. Snowy egret and black-crowned night-heron annual exposure to mercury, 1997-2006. Arch Environ Contam Toxicol 53:269-280

Hill EF, Henny CJ, Grove RA (2008) Mercury and drought along the lower Carson River, Nevada: II. Snowy egret and black-crowned night-heron reproduction on Lahontan Reservoir, 1997-2006. Ecotoxicology 17:117-131

Hoffman DJ, Henny CJ, Hill EF, Grove RA, Kaiser JL, Stebbins KR (2009) Mercury and drought along the lower Carson River, Nevada: III. Effects on blood and organ biochemistry and histopathology of snowy egrets and black-crowned night-herons on Lahontan Reservoir, 2002-2006. J Toxicol Environ Health Part A 72:1223-1241

Hoffman RJ, Taylor RL (1998) Mercury and suspended sediment, Carson River Basin, Nevada Loads to and from Lahontan Reservoir in flood year 1997 and deposition in reservoir prior to 1983. U S Geological Survey, Fact Sheet FS-001-98, Carson City, NV 
Hoffman RJ, Thomas KA (2000) Methylmercury in water and bottom sediment along the Carson River system, Nevada and California, September 1998. U S Geological Survey, WaterResources Investigations Report 00-4013

Jenness J (2012) Polar plots and circular statistics extension for ArcGIS. Jenness Enterprises. Available at: http://www.jennessent.com/arcgis/PolarPlots.htm Accessed 18 May 2015.

Lawrence SJ (2003) Mercury in the Carson River Basin, Nevada. In: Gray JE (ed) Geologic studies of mercury by the U.S. Geological Survey. U S Geological Survey, Circular 1248, pp 29-33

Nagler PL, Glenn EP, Hinojosa-Huerta O (2009) Synthesis of ground and remote sensing data for monitoring ecosystem functions in the Colorado River Delta, Mexico. Remote Sensing Environ. $113: 1473-1485$

Newton I (1986) The sparrowhawk. T \& AD Poyser, Ltd., Calton, England

Palmer RS (ed) (1962) Handbook of North American birds, Vol. 1. Loons to flamingos. Yale Univ. Press, New Haven, CT

SAS Institute (1999) SAS User's Guide: Statistics, Version 8.02. SAS Institute, Inc., Cary, NC

Seber GAF (1972) The estimation of animal abundance and related parameters, $2^{\text {nd }}$ edn. Macmillan, New York

Smith GH (1943) The history of the Comstock Lode, 1850-1920. Nevada Bureau of Mines and Geology. Bull. 37

Spalding MG, Frederick PC, McGill HC, Bouton SN, McDowell LR (2000) Methylmercury accumulation in tissues and its effects on growth and appetite in captive great egrets. J Wildl Dis $36: 411-422$

Streby HM, Refsnider JM, Anderson DE (2014) Redefining reproductive success in songbirds: Moving beyond the nest success paradigm. Auk 131:718-726

U S Geological Survey (2008) Watershed Boundary Data: The 8, 10, and 12 hydrologic unit boundaries for Nevada. http://nhdftp.usgs.gov/ Accessed 15 October 2014

Van Denburgh AS (1973) Mercury in Carson and Truckee River Basins in Nevada. U S Geological Survey, Open-File Report 73-352 
Wayne DM, Warwick JJ, Lechler PJ, Gill GA, Lyons WB (1996) Mercury contamination on the Carson River, Nevada: A preliminary study of the impact of mining wastes. Water Air Soil Pollut 92:391-408

Wentz DA, Brigham ME, Chasar LC, Lutz MA, Krabbenhoft DP (2014) The quality of our Nation's waters: Mercury in the Nation's streams-levels, trends and implications. U S Geological Survey, Circular 1395

White GC, Burnham KP (1999) Program MARK: Survival estimation from populations of marked animals. Bird Study 46(suppl.): 120-138

\section{Compliance with ethical standards}

Informed consent Informed consent was obtained from individual participants included in the study. 
Table 1. Age and body weight (arithmetic means) and blood THg ( $\mu \mathrm{g} / \mathrm{g} \mathrm{ww}$ ) concentrations (geometric means) from young snowy egrets bled in Nevada in 2002, 2003 and 2004.

\begin{tabular}{|c|c|c|c|c|c|c|}
\hline \multirow[b]{2}{*}{ Category } & \multicolumn{2}{|c|}{2002} & \multicolumn{2}{|c|}{2003} & \multicolumn{2}{|c|}{2004} \\
\hline & LR & REF & LR & REF & LR & REF \\
\hline $\mathrm{N}$ & 11 & 21 & 31 & $32^{\mathrm{a}}$ & $50^{\mathrm{b}}$ & $25^{\mathrm{c}}$ \\
\hline Age (days) & $18.4 \mathrm{~A}$ & $19.8 \mathrm{~A}$ & 18.6 B & $20.5 \mathrm{~A}$ & $19.5 \mathrm{~A}$ & $18.5 \mathrm{~A}$ \\
\hline Body wt. (g) & 296 A & $304 \mathrm{~A}$ & $326 \mathrm{~B}$ & 359 A & $330 \mathrm{~A}$ & $325 \mathrm{~A}$ \\
\hline Blood THg & $1.47 \mathrm{~A}$ & 0.68 B & $3.39 \mathrm{~A}$ & 0.71 B & 1.89A & 0.67 B \\
\hline
\end{tabular}

Note: Comparisons between Lahontan Reservoir (LR) and the Humboldt River (REF) for same year that were significantly different $($ alpha $=0.05)$ are in bold print.

${ }^{\text {a }}$ Sample size 32, except for blood THg $(\mathrm{N}=7)$.

${ }^{\mathrm{b}}$ Sample size 50, except for blood THg $(\mathrm{N}=43)$.

${ }^{c}$ Sample size 25, except blood THg $(\mathrm{N}=10)$.

Table 2. Age at dispersal (days) and Julian date of dispersal for young snowy egrets at Lahontan Reservoir (LR) and Humboldt River Reference Area (REF) in Nevada, 2002, 2003 and 2004.

\begin{tabular}{lcccc}
\hline Location & 2002 & 2003 & 2004 & $2002-2004$ \\
\cline { 1 - 3 } Age at dispersal & & & & \\
LR Mean & $(54.0) *$ & $50.8 \mathrm{~A} \mathrm{a}$ & $55.5 \mathrm{~B} \mathrm{a}$ & $53.5 \mathrm{a}$ \\
SD (N) & $4.36(3)$ & $4.12(22)$ & $4.45(29)$ & $4.81(54)$ \\
REF Mean & $46.8 \mathrm{~B}$ & $48.7 \mathrm{~B} \mathrm{a}$ & $54.4 \mathrm{~A} \mathrm{a}$ & $49.5 \mathrm{~b}$ \\
SD (N) & $7.91(23)$ & $5.47(34)$ & $4.06(19)$ & $6.64(76)$ \\
\hline Julian date dispersal & & & $216.7 \mathrm{a}$ \\
LR Mean & $(222.0) *$ & $225.3 \mathrm{~A} \mathrm{a}$ & $209.7 \mathrm{~B} \mathrm{a}$ & $9.08(54)$ \\
SD (N) & $7.55(3)$ & $4.94(22)$ & $4.68(29)$ & $218.5 \mathrm{a}$ \\
REF Mean & $220.0 \mathrm{~A}$ & $222.4 \mathrm{~A} \mathrm{a}$ & $209.7 \mathrm{~B} \mathrm{a}$ & $8.22(76)$ \\
SD (N) & $8.17(23)$ & $6.25(34)$ & $3.89(19)$ & \\
\hline
\end{tabular}

Note: * No statistical tests with 2002 LR (only 3 samples). Comparisons among years at the same location are shown by upper case letters. Years sharing same letter not significantly different. Comparisons between locations during the same year shown by lower case letters, again years sharing same letter not significantly different. 
Table 3. Young snowy egrets with telemetry radios attached at Lahontan Reservoir (LR) and Humboldt River Reference Area (REF), number known to have died "in colony" before dispersing, and after dispersing but before migration.

\begin{tabular}{|c|c|c|c|c|}
\hline & 2002 & 2003 & 2004 & Total \\
\hline \multicolumn{5}{|l|}{ Lahontan Reservoir (LR) } \\
\hline Attached & 10 & 23 & 38 & 71 \\
\hline Died "in colony" & $7(70 \%)$ & $1(4.3 \%)$ & $6(15.8 \%)$ & $14(19.7 \%)$ \\
\hline Dispersed & 3 & 22 & $32(29)^{a}$ & $57(54)^{a}$ \\
\hline Died after dispersal & 0 & $1(4.5 \%)$ & $4(12.5 \%, 13.8 \%)^{b}$ & $5(8.8 \%, 9.3 \%)^{b}$ \\
\hline \multicolumn{5}{|l|}{ Reference Area (REF) } \\
\hline Attached & 24 & 35 & 20 & 79 \\
\hline Died "in colony" & $1(4.2 \%)$ & $1(2.9 \%)$ & $1(5.0 \%)$ & $3(3.8 \%)$ \\
\hline Dispersed & $23(22)^{a}$ & 34 & 19 & $76(75)^{a}$ \\
\hline Died after Dispersal $\quad 8$ & $8(34.8 \%, 36.4 \%)^{b}$ & $7(20.6 \%)$ & $4(21.1 \%)$ & $19(25.0 \%, 25.3 \%)^{b}$ \\
\hline \multicolumn{5}{|c|}{$\begin{array}{l}\text { a ( ) Excludes } 3 \text { egrets at LR in } 2004 \text { and } 1 \text { egret at REF in } 2002 \text { with no signal received after dispersing } \\
\text { from colony. } \\
\text { b ( ) Second percentage excludes egrets with no signal received after dispersal, excluded in } X^{2} \text { tests. }\end{array}$} \\
\hline Died "in colony" (LR vs. REF & \multicolumn{2}{|c|}{$\begin{array}{l}2002 X^{2}=17.0, P=0.00004 \\
2004 X^{2}=1.44, P=0.231\end{array}$} & \multicolumn{2}{|c|}{$\begin{array}{cl}2003 & X^{2}=0.093, P=0.760 \\
2002-04 & X^{2}=9.43, P=0.002\end{array}$} \\
\hline Died after dispersing (LR v & $\begin{array}{rr}\text { vs. REF) } 2002 \quad X^{2}= \\
2004 \quad X^{2}=\end{array}$ & $\begin{array}{l}60, P=0.205 \\
36, P=0.509\end{array}$ & $\begin{aligned} 2003 & X^{2}=2.81 \\
2002-04 & X^{2}=5.36\end{aligned}$ & $\begin{array}{l}=0.094 \\
=0.021\end{array}$ \\
\hline
\end{tabular}




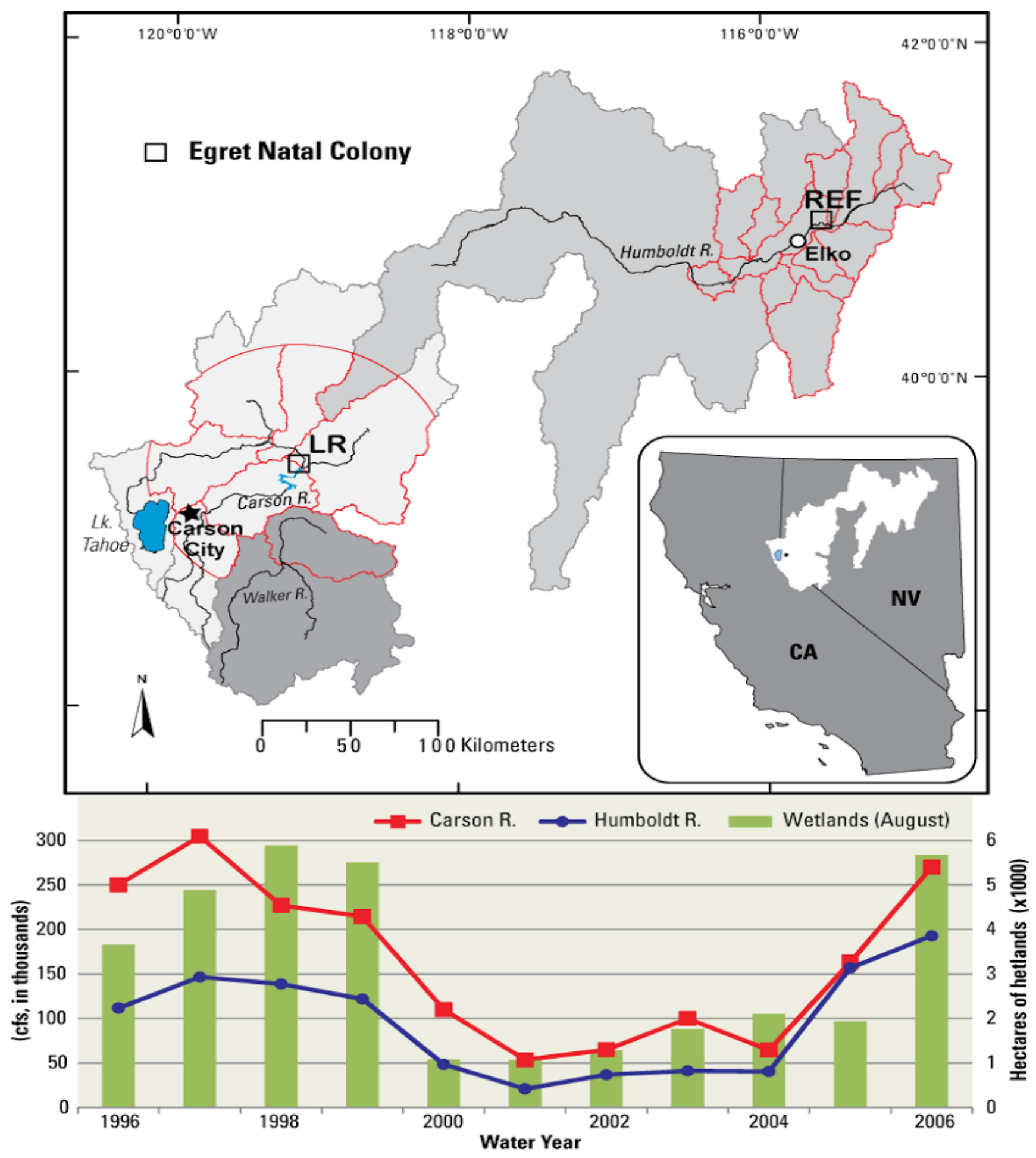

Figure 1. Locations of the two snowy egret nesting colonies studied on Lahontan Reservoir (LR) and Humboldt River (REF) with total annual water discharge (water years 1996-2006) on Carson River at Fort Churchill, and Humboldt River near Elko, Nevada (USGS Water Resources Data, Carson City, NV), and hectares of wetlands at Stillwater NWR Complex in August 1996-2006 (Bill Henry, USFWS, Complex files, Fallon, NV). 


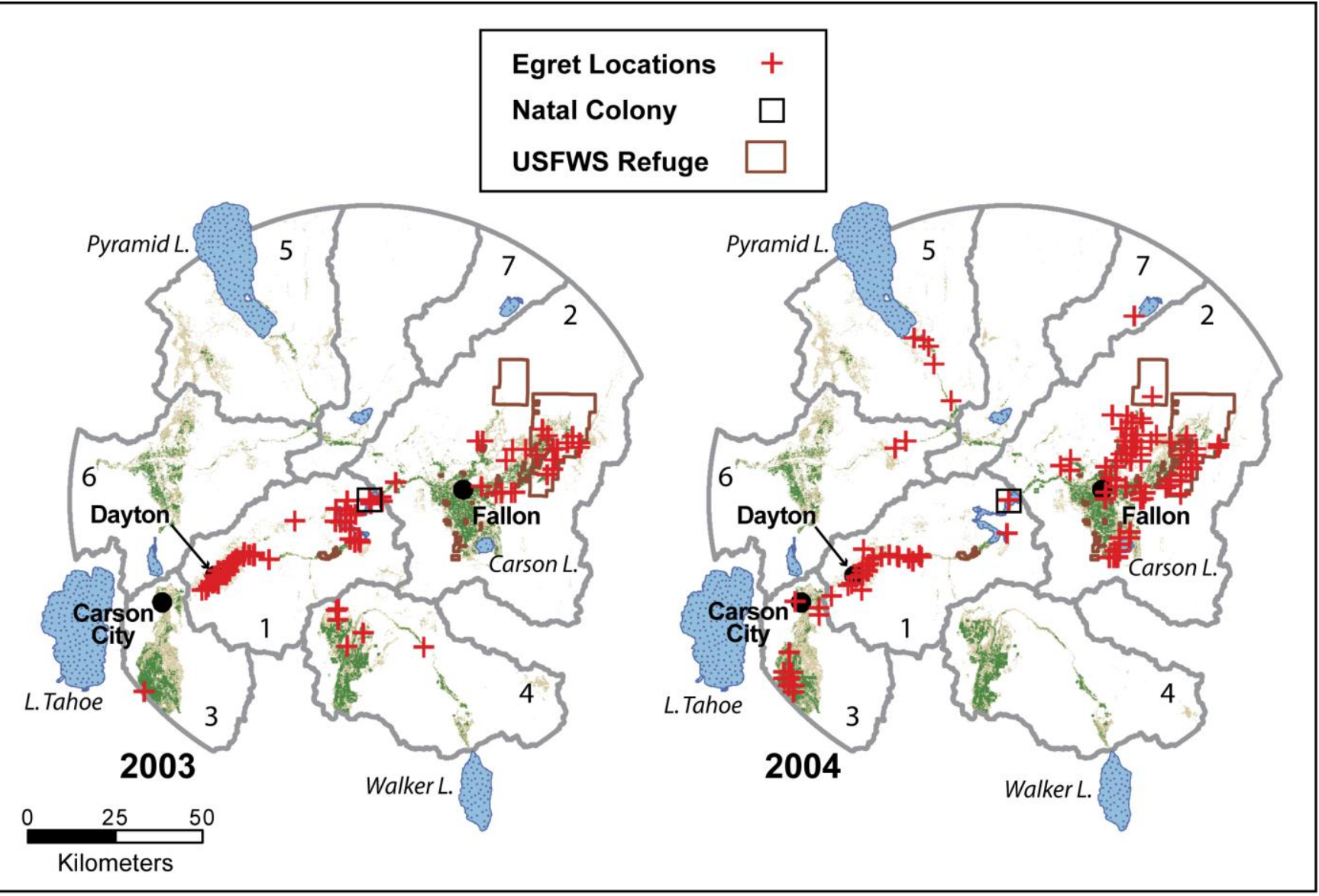

Figure 2. Geographical distribution of young snowy egrets that dispersed from the natal colony at Lahontan Reservoir (LR), 2003 and 2004. Names of Hydrologic Units include: 1 Middle Carson (high mercury), 2 Carson Desert (lower mercury), 3 Upper Carson, 4 Walker, 5 Pyramid-Winnemucca, 6 Truckee, 7 Lower Humboldt. Note: this Figure represents pooled observations for weekly aerial surveys and thus includes repeats of the same egrets. Higher (>0.3) August/September NDVI values, shown in green, reflect areas of irrigation or riparian vegetation. 


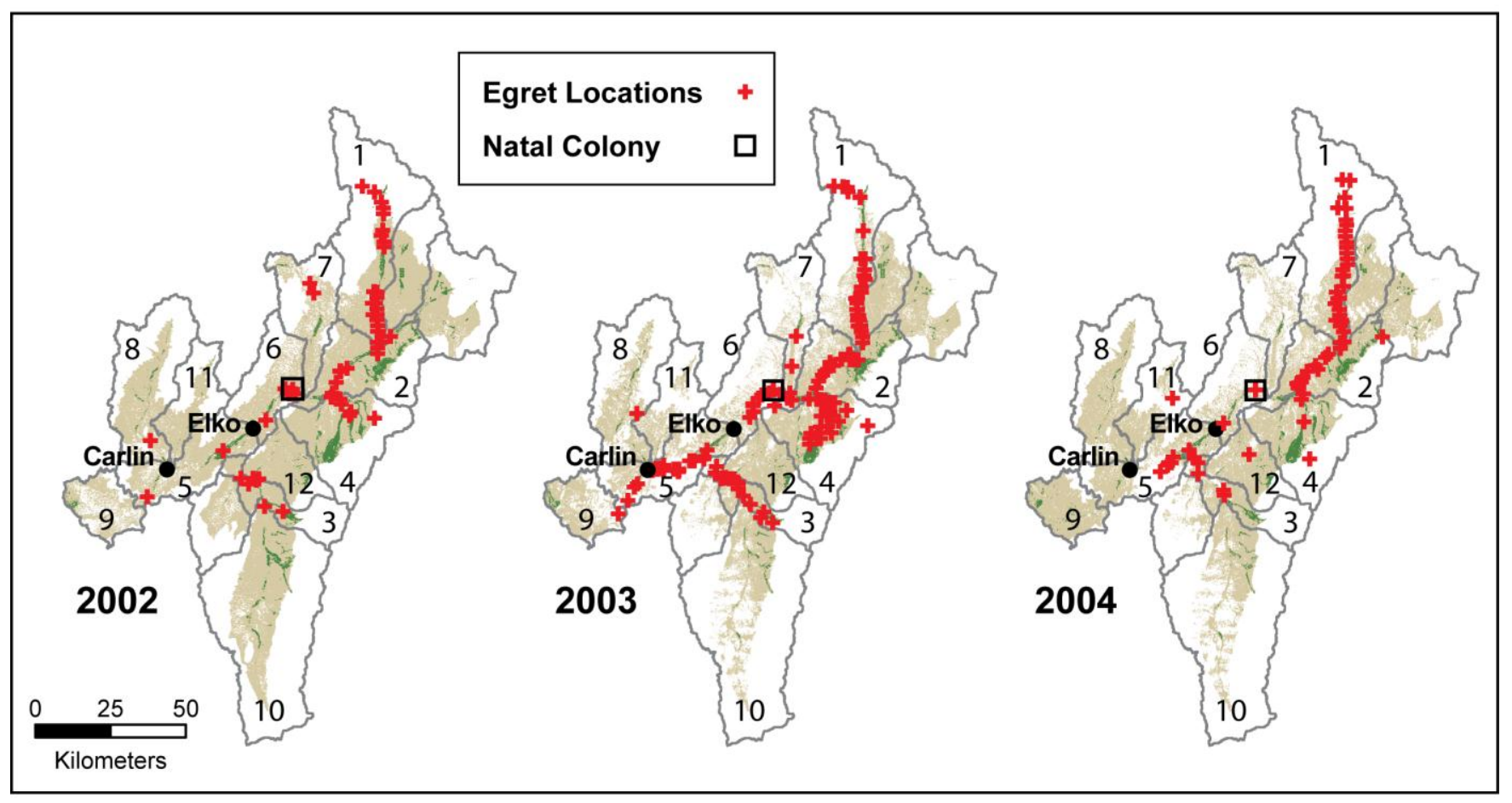

Figure 3. Geographical distribution of young snowy egrets that dispersed from the natal colony at the Humboldt River Reference Area (REF) near Elko, Nevada, 2002, 2003 and 2004. Names of Hydrologic Units include: 1 Mary's River, 2 Reed Creek-Humboldt, 3 S. Fork Humboldt, 4 Lamoile-Secret Creeks, 5 Dry Susie CreekHumboldt, 6 Coal Mine Creek-Humboldt, 7 Lower N. Fork Humboldt, 8 Maggie Creek, 9 Bob Creek-Humboldt, 10 Huntington Creek, 11 Susie Creek, 12 Ten Mile Creek. Note: this Figure represents pooled observations for weekly aerial surveys and thus includes repeats of the same egrets. NDVI (>0.3) is shown as in Fig. 2. 

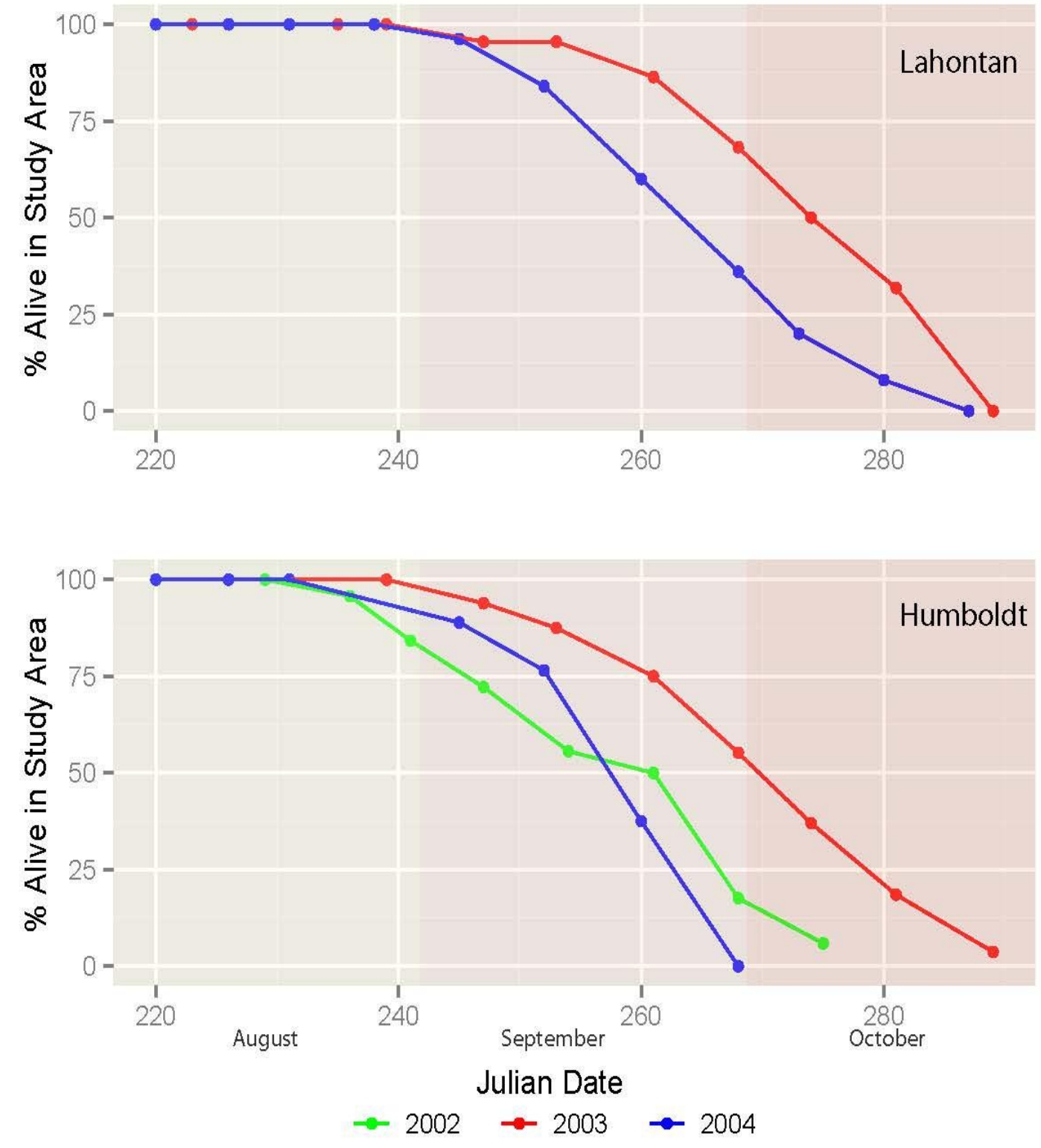

Figure 4. Timing of annual migration of young snowy egrets from Lahontan Reservoir (LR) and Humboldt River Reference Area (REF) in 2002, 2003 and 2004 as determined from weekly aerial surveys with month and Julian date on $x$-axis. 

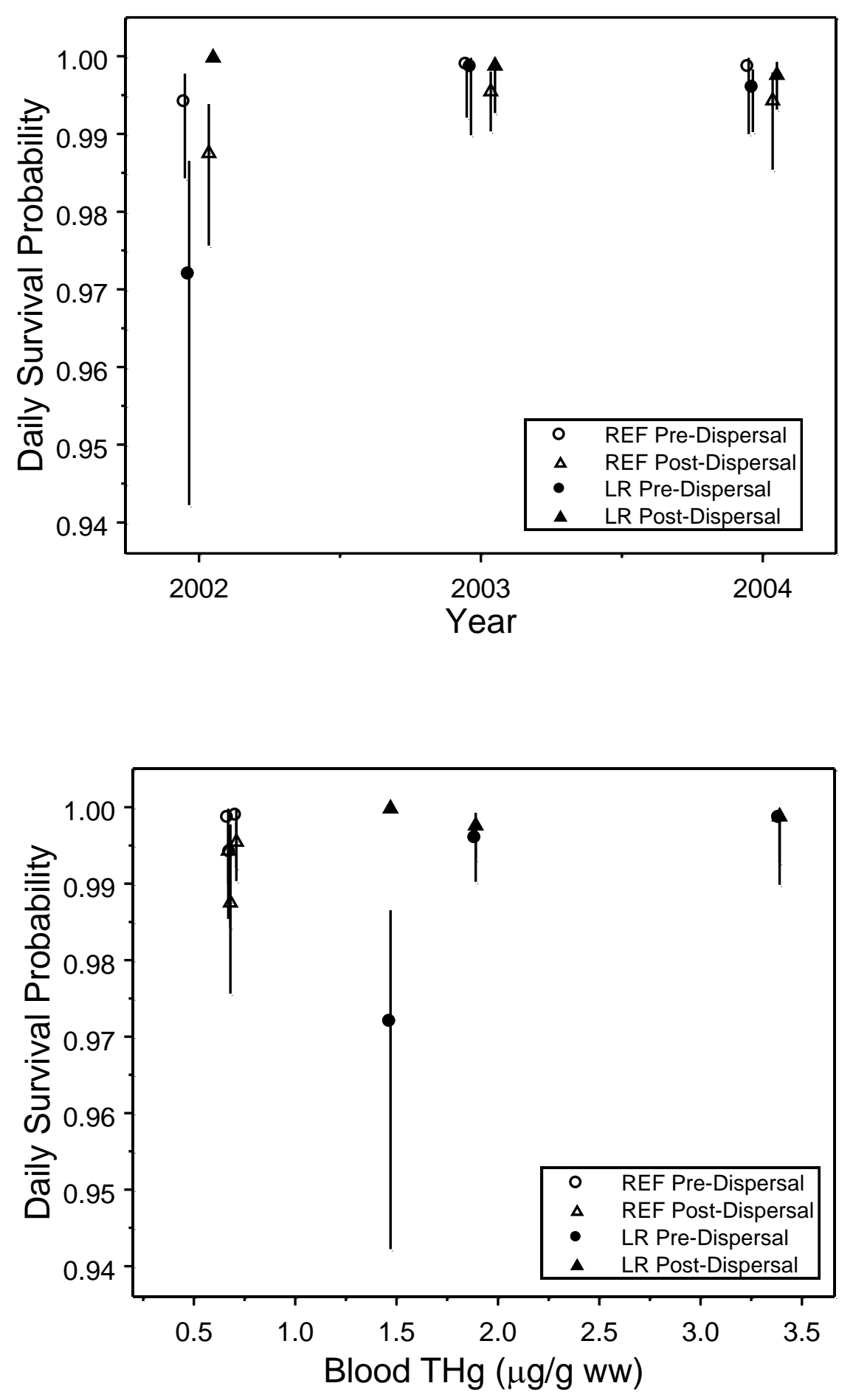

Figure 5. Daily survival rates (and 95\% confidence interval) from full model for young snowy egrets from Lahontan Reservoir (LR) and Humboldt River Reference Area (REF) during pre-dispersal and post-dispersal periods 2002, 2003 and 2004, plus daily survival rates from LR and REF during pre-dispersal and post-dispersal periods related to geometric mean THg concentrations in blood at 20 days of age in 2002, 2003 and 2004. 